\title{
DOCTRINA
}

\section{DERECHOS HUMANOS Y DELITOS DE LESA HUMANIDAD}

\section{UN ANÁLISIS DE LA JURISPRUDENCIA DE LA SUPREMA CORTE DE JUSTICIA SOBRE IMPRESCRIPTIBILIDAD DE LOS DELITOS DE LA DICTADURA}

\begin{abstract}
RESUMEN. Las declaraciones de derechos humanos de 1948 -americana y universal- reconocieron derechos a la vida, libertad y seguridad, prohibieron la tortura y otros tratos o penas crueles, inhumanas o degradantes y exigieron un recurso efectivo contra actos que violenten derechos fundamentales. Setenta años después, Uruguay sigue discutiendo la impunidad de los delitos cometidos en el marco del terrorismo de Estado. Sucesivos obstáculos han bloqueado los avances de jueces y tribunales hacia la identificación y procesamiento de los responsables. El más reciente es la jurisprudencia de la SCJ que rechaza por mayoría la imprescriptibilidad de esos delitos. Mi propósito es analizar la argumentación que sustenta esa decisión.
\end{abstract}

Alicia Castro*

ABSTRACT. The 1948 Human Rights Declarations, both the American and the Universal, recognized the rights to life, freedom and security, prohibited torture and other cruel, inhuman or degrading treatments or punishment, and required an effective remedy against acts violating fundamental rights. Seventy years later, Uruguay still discusses over impunity of crimes committed within State terrorism. Progress made by judges and Courts towards the identification and prosecution of those responsible has been blocked by subsequent hindrances. The most recent Supreme Court of Justice case law rejects by majority vote the imprescriptibility of such crimes. The purpose of this paper is to analyze the arguments underpinning such decision.

*Doctora en Derecho y Ciencias Sociales, Profesora Agregada en Filosofía del Derecho, actual Directora del Instituto de Filosofía y Teoría General del Derecho, Ex- Magistrada Judicial y ex- Presidenta del Tribunal de lo Contencioso Administrativo. Correo electrónico: aliciacastrorivera@gmail.com 
KEY WORDS. Crimes Against Humanity. Human Rights. Imprescriptibility. Law $n^{\circ} 18,831$. Transitional Justice. Expiry Law. Unconstitutionality. Ius cogens.

PALABRAS CLAVES. Delitos de Lesa Humanidad. Derechos Humanos. Imprescriptibilidad . Ley $\mathrm{N}^{\circ}$ 18.831. Justicia transicional. Ley de Caducidad. Inconstitucionalidad. Ius cogens.

\section{PROPUESTA}

En 1948, un amplio conjunto de naciones concluía que “... la libertad, la justicia y la paz en el mundo tienen por base el reconocimiento de la dignidad intrínseca y de los derechos iguales e inalienables de todos los miembros de la familia humana" ${ }^{1}$ ). En la Declaración Americana de los Derechos y Deberes del Hombre aprobada en la IX Conferencia Internacional Americana en Bogotá en abril y en la Declaración Universal de Derechos Humanos aprobada por la Asamblea General de las Naciones Unidas el 10 de diciembre, fue reconocido el derecho de todas las personas a la vida, integridad física y psíquica, libertad y seguridad entre muchos otros, poniendo énfasis en la prohibición de la tortura u otros tratos o penas crueles, inhumanas o degradantes, así como en el derecho a un recurso rápido y efectivo ante los tribunales nacionales contra actos que violen derechos fundamentales.

La comunidad internacional había comprendido que, para poder salir del delirio y la alienación provocados por regímenes autoritarios que habían incurrido en violaciones graves y sistemáticas de esos derechos de las personas, era necesario restablecer la continuidad institucional y juzgar los crímenes cometidos. Comprendió que no puede haber paz sin justicia, por lo menos sin un mínimo de justicia. Es el origen de la idea de justicia transicional que todavía cuesta comprender y practicar.

A setenta años de esas declaraciones, más de treinta de los Pactos Internacionales de Derechos y casi treinta de la Convención Americana de Derechos Humanos, persisten en Uruguay obstáculos para cumplir con el imperativo de establecer la verdad y hacer justicia en los crímenes de lesa humanidad del pasado reciente. Al día de hoy, no hemos resuelto el problema de la impunidad de los delitos contra los derechos humanos de muchos uruguayos durante el período de crisis del orden constitucional que llevó al gobierno de facto que terminó el 28 de febrero de 1985.

Nadie cuestiona seriamente la existencia ni la gravedad de esas conductas, pero la investigación y el juzgamiento de sus autores ha encontrado obstáculos que han dificultado el avance de jueces y tribunales en la averiguación y juzgamiento de los responsables. Esto es reprochado con insistencia por organizaciones sociales que reclaman verdad y justicia y es reiteradamente observado por los organismos internacionales que monitorean el cumplimiento del Derecho Internacional de los Derechos Humanos por los Estados Partes.

Si bien el primer obstáculo fue la Ley $\mathrm{N}^{\circ} 15.848$ de 22.12.1986, que declaróla caducidad de la pretensión punitiva estatal y confirió al Poder Ejecutivo la facultad de decidir si cada denuncia encuadraba o no en el marco de esa indisimulada amnistía, el obstáculo actual

${ }^{1}$ Preámbulo de la Declaración Universal de Derechos Humanos 
es la discusión sobre la prescripción de los delitos amparados por aquella ley y la constitucionalidad de los arts.2 y 3 de la Ley $\mathrm{N}^{\circ} 18.831$ de 26.10.2011.

Mi propósito es analizar un problema jurídico que no ha podido ser resuelto porque desde que se planteó, hace siete años, nuestra Suprema Corte de Justicia ha dictado decisiones contradictorias dependientes de mayorías circunstanciales, acerca de la prescriptibilidad o imprescriptibilidad de los delitos cuya investigación obstaba la Ley $\mathrm{N}^{\circ} 15.848$ de 22.12.1986. El resultado de esa jurisprudencia aleatoria no puede ser más desconcertante para quienes siguen reclamando por la violación de sus derechos, para quienes son indagados en esas causas y para el conjunto de la población que se interesa en estos temas.

Ofrezco una síntesis de los argumentos formulados en sentencias a favor o en contra de la imprescriptibilidad de esos delitos -que sintetiza la reciente sentencia SCJ 680/2017y algunas observaciones críticas a la argumentación jurídica mayoritaria.

\section{ESTADO DE SITUACIÓN}

En líneas generales, desde el 1.3.1985 se inician numerosas indagatorias judiciales por hechos de privación de libertad, lesiones, violaciones, homicidio, que fueron delitos según el derecho penal uruguayo de la época. En ese contexto, el 22.12.1986 se dictó la Ley Nº 15.848 de Caducidad de la Pretensión Punitiva del Estado que permitió al Poder Ejecutivo impedir las indagatorias judiciales. El 2.5.1988, por sentencia SCJ 184/1988 -dictada por mayoria con tres votos- la Suprema Corte de Justicia desestimó la acción de inconstitucionalidad promovida contra los arts. 1 a 4 de dicha Ley y, más tarde, el 16.4.1989 fracasó el recurso de referendum contra esa ley, al obtener en el plebiscito convocado sólo el 42,4\% de los votos.

Más de veinte años después la SCJ por sentencia $N^{\circ} 365$ de 19.10.2009, declaró la inconstitucionalidad de la Ley $\mathrm{N}^{\circ} 15.848$ y habilitó el juzgamiento de un caso -y luego de otros- dando claras señales del camino a seguir para habilitar la investigación de los hechos denunciados.

Debido al tiempo transcurrido entre el momento en que fueron cometidos los delitos, todos anteriores al 1.3.1985, el momento en que fueron denunciados y el momento en que pudiera recaer sentencia de condena, apareció segundo obstáculo: la aplicación de normas penales nacionales sobre la prescripción de delitos hacía inminente la prescripción extintiva de todos los delitos antes alcanzados por la ley de caducidad.

Queriendo evitar ese efecto y, a la vez, dar cumplimiento a la Sentencia dictada por la Corte Interamericana de Derechos Humanos el 22.2.2011 en el Caso Gelman vs. Uruguay, se dictaron el Decreto 322/011 de 30.6.2011 que revocó por razones de legitimidad los actos del Poder Ejecutivo que habían impedido la investigación de denuncias y la Ley No.18.831 de 27.10.2011 que restableció el pleno ejercicio de la pretensión punitiva del Estado para los delitos cometidos en aplicación del terrorismo de Estado hasta el $1^{\circ}$ de marzo de 1985, comprendidos en la Ley $\mathrm{N}^{0} 15.848$ (art.1), declarando que fueron crímenes de lesa humanidad de conformidad con los tratados internacionales (art.3) e impidió computar plazo de prescripción o caducidad por el período comprendido entre el 22.12.1986 y la entrada en vigencia de esta ley (art.2). 
A partir de entonces, la defensa de los imputados ha planteado reiteradamente la inconstitucionalidad de los artículos 2 y 3 y la prescripción de los delitos que se investigan. La Suprema Corte ha reflejado desacuerdos, tomando decisiones erráticas, en que domina la tendencia a admitir la prescripción.

La primer sentencia que aborda ese problema -ante un recurso de casación penal de sentencia de condena- rechaza la prescripción pero ya muestra una división en su enfoque del tema, con discordia del Ministro Dr.Van Rompaey $\left({ }^{2}\right)$. Con posterioridad, admitiendo un recurso inadmisible $\left(^{3}\right)$, fueron casadas sentencias interlocutorias que rechazaban la prescripción, y mayoritariamente admitidas excepciones de inconstitucionalidad contra los arts. 2 y 3 de la Ley $\mathrm{N}^{\circ} 18.831\left(^{4}\right)$.

Como adelanté este trabajo, se centra en la sentencia SCJ 680/2017 de 25.9.2017, que representa la posición de la Suprema Corte en su última integración, a la que se remite en las decisiones adoptadas este año $\left({ }^{5}\right)$.

Es claro que, aunque en la mayoría de las sentencias, la cuestión a resolver es la inconstitucionalidad de la Ley $\mathrm{N}^{\circ} 18.831$ en cuanto declara la imprescriptibilidad de los delitos protegidos por la Ley $\mathrm{N}^{\circ} 15.848$, la decisión de la Suprema Corte expresa su posición sobre la prescriptibilidad de los delitos investigados en esas causas $\left(^{6}\right)$.

\section{ARGUMENTOS A FAVOR DE LA PRESCRIPCIÓN O DE LA INCONSTITUCIONALIDAD DE LA LEY 18.831, QUE LOS DECLARA “DELITOS DE LESA HUMANIDAD” IMPRESCRIPTIBLES.}

La mayoría que decide en la sentencia SCJ 680/2017, en su fundamentación remite a lo expresado en las sentencias SCJ 20/2013 de 22.2.2013 y SCJ 1501/2011 de 6.5.2011, ambas dictadas por integraciones anteriores, que -con discordias- aceptaron la prescriptibilidad de los delitos que estuvieron amparados por la Ley $\mathrm{N}^{\circ} 15.848$ y la inconstitucionalidad de la Ley $\mathrm{N}^{\circ} 18.831$ en sus arts. 2 y 3 . A lo que agrega argumentos para refutar la tesis de la imprescriptibilidad como fuera sostenida por el Ministro Dr. Cardinal (en integración) y por el Ministro Dr. Hounie en adelante.

\footnotetext{
${ }^{2}$ SCJ Sentencia 1501/2011 de 6.5.2011, aclarada por Resolución 887 de 30.5.2011. Caso Gavazzo, Arab y otros y también SCJ Sentencia 2294/2011 de 20.7.2011

${ }^{3}$ Según el Código del Proceso Penal vigente entonces art.269 "procede el recurso de casación por infracción de la Ley en el fondo o en la forma, contra todas las sentencias dictadas en la segunda instancia, así como las resoluciones de segunda instancia que pongan fin a la acción penal o hagan imposible su continuación" Sin embargo, rechazado por SCJ Sentencia 1620/2014 de 10.9.2014, se revocó y admitió por SCJ Sentencia 2123/2014 de 24.11.2014. Actualmente la SCJ mantiene el criterio correcto y no admite el recurso en tales casos SCJ Sentencia 2433/2017 de 20.12.2017.

${ }^{4}$ Salvo cuando mayorías circunstanciales llegaron a desestimar totalmente la impugnación

${ }^{5}$ SCJ Sentencia 658/2018

${ }^{6}$ RISSO FERRAND, Martín. "Cumplimiento de la sentencia de la Corte Interamericana de Derechos Humanos en el caso Gelman. Después de la declaración de inconstitucionalidad de la Ley Interpretativa 18.831” en Anuario de Derecho Constitucional Latinoamericano Año XIX Bogotá, 2013, p.639-653. En ese trabajo el Prof.Risso señala que la Ley $\mathrm{N}^{\circ} 18.831$ no tiene otra consecuencia que facilitar a los indagados la posibilidad de oponer la excepción para dilatar el avance de la causa porque no impide que aún después de que se declare la inconstitucionalidad, el juez prosiga investigando y que el problema deba ser analizado finalmente si recae condena, cuando llegue a casación penal, siempre que se mantenga la posición hoy mayoritaria.
} 
El argumento central es que las conductas delictivas que puedan haberse cometido en nuestro territorio durante el período de ruptura del orden constitucional deben ser juzgadas según la ley penal nacional vigente al tiempo en que ocurrieron, lo que excluye toda posibilidad de condenar a ningún imputado por delitos que no estaban tipificados en la legislación penal nacional de entonces o imponerles una pena más severa.

Nuestro derecho penal prevé la prescripción como modo de extinguir los delitos cuando ha pasado determinado tiempo de que fueron consumados sin que haya recaído sentencia de condena. Como los delitos a que refiere la Ley $\mathrm{N}^{\circ} 15.848$ deben ser juzgados según el derecho penal uruguayo vigente entonces, no es posible negar la prescripción, puesto que cuando se cometieron eran prescriptibles.

La incorporación al derecho uruguayo de los "delitos de lesa humanidad" y su imprescriptibilidad resulta de leyes posteriores que, entre 2001 y 2006, ratificaron la Convención sobre la imprescriptibilidad de los Crímenes de guerra y Crímenes de lesa humanidad (1968) y el Estatuto de Roma de la Corte Penal Internacional (1998), siendo que recién por Ley $\mathrm{N}^{\circ}$ 18.026 de 25.9.2006 se incorporan a nuestra legislación penal “crímenes de lesa humanidad" y se establece su imprescriptibilidad $\left({ }^{7}\right)$.

Sostener que fueron delitos de lesa humanidad y por tanto, imprescriptibles es claramente contrario a principios fundamentales recogidos por la Constitución Nacional, como el principio de legalidad y el principio de irretroactividad de la ley penal más gravosa, expresados en el viejo adagio nullum crimen, nulla poena sine lege, cuya larga historia y amplia recepción en el mundo se reseña extensamente. Esos principios están incorporados a nuestra Constitución en el art.10 y también en el art.72.

En el precedente invocado -SCJ 20/2013 de 22.2.2013- el Ministro Dr. Chalar, ensayó respaldar la tesis de la prescripción con una extensa referencia al Derecho Internacional de los Derechos Humanos, citando en particular el Pacto Internacional de Derechos Civiles y Políticos, la Convención Americana de Derechos Humanos y el Estatuto de Roma $\left(^{8}\right)$.

${ }^{7}$ La Ley $\mathrm{N}^{\circ} 17.347$ de 13.6.2001 ratifica la Convención sobre la Imprescriptibilidad de los Crímenes de Guerra y de los Crímenes de Lesa Humanidad del 26.11.1968. Según la tesis mayoritaria, todas las convenciones internacionales que declaran imprescriptibles y ordenan investigar y sancionar conductas de tortura y otros tratos o penas crueles, inhumanos o degradantes, desaparición forzada de personas y otros delitos de lesa humanidad fueron ratificadas por leyes dictadas con posterioridad al 1.3.1985, o sea, posteriores a la época en que ocurrieron los hechos que se juzgan. Por tanto, ninguna de esas normas puede aplicarse en estos procesos.

${ }^{8}$ Pacto Internacional de Derechos Civiles y Políticos (1966), ratificado por Ley 13.751 de 11.7.1969. Art.14 num.7: "Nadie podrá ser juzgado ni sancionado por un delito por el cual haya sido ya condenado o absuelto por una sentencia firme de acuerdo con la ley y el procedimiento penal de cada país" Art.15. "Nadie será condenado por actos u omisiones que en el momento de cometerse no fueran delictivos según el derecho nacional o internacional. [...] Nada de lo dispuesto en este artículo se opondrá al juicio ni a la condena de una persona por actos u omisiones que, en el momento de cometerse, fueran delictivos según los principios generales del derecho reconocidos por la comunidad internacional" Convencion Americana de DDHH (1969), ratificada por Ley 15.837 de 8.3.1985. Articulo 7. 1. Toda persona tiene derecho a la libertad y a la seguridad personales. 2. Nadie puede ser privado de su libertad física, salvo por las causas y en las condiciones fijadas de antemano por las Constituciones Políticas de los Estados Partes o por las leyes dicta. Articulo 8.4: "El inculpado absuelto por una sentencia firme no podrá ser sometido a juicio por los mismos hechos". Artículo 9. Principio de Legalidad y de Retroactividad. Nadie puede ser condenado por acciones $u$ omisiones que en el momento de cometerse no fueran delictivos e. Tampoco se puede imponer pena más grave que la aplicable al momento de la comisión del delito. Si con posterioridad a la comisión del delito la ley dispone la imposición de una pena más leve, el delincuente se beneficiará de el. 
Expresando que "nada puede justificar que el Estado-parte de dichos sistemas deba o pueda llevar a cabo acciones que sean contrarias a los Derechos Humanos reconocidos a los individuos por su legislación interna, tanto como por la normativa con fuente en tales sistemas. No existe pretexto que justifique ignorar la normativa tutelar de derechos fundamentales" $\left({ }^{9}\right)$, sostuvo aceptar la imprescriptibilidad de los delitos indagados violentaba los derechos humanos de los eventuales encausados, por lo que debía ser rechazada.

En la misma sentencia, la Corte rechazó el argumento de que el fallo de la Corte Interamericana de Derechos Humanos del 24.2.2011 en el Caso Gelman vs. Uruguay, le obligara a rechazar la prescripción de los delitos indagados en otros casos, sosteniendo que no está alcanzada por la cosa juzgada y marcando su discrepancia con dos tesis fuertes de la Corte supranacional: el valor que atribuye a su jurisprudencia interpretativa como precedente vinculante y su exigencia de que los jueces y tribunales nacionales realicen un control de convencionalidad de las normas nacionales que vayan a aplicar.

Para rebatir la tesis de la imprescriptibilidad, la mayoría ahora cita opiniones del Prof.Cajarville, del constitucionalista Martin Risso y del teórico alemán Rober Alexy y sostiene que el ingreso de normas internacionales de derechos humanos por la vía del art.72 de la Constitución, estaría sujeto a la condición de que los nuevos derechos no entraran en colisión con los derechos reconocidos antes en nuestra Constitución Nacional: hay que hacer un esfuerzo de armonización y, en el caso excepcional en que no se logre, hay que decidir cuál debe prevalecer. La imprescriptibildiad colide con los derechos de libertad y seguridad jurídica, incorporados en el texto y pese a que concluye que "nada impide la armonización de tales derechos, manteniendo el contenido esencial de cada uno de ellos, sin sacrificar a ninguno", en el fallo opta por los segundos. $\left({ }^{10}\right)$.

Articulo 29. Ninguna disposición de la presente Convención puede ser interpretada en el sentido de: a) permitir a alguno de los Estados Partes, grupo o persona, suprimir el goce y ejercicio de los derechos y libertades reconocidos en la Convención o limitarlos en mayor medida que la prevista en ella. Estatuto de Roma (1998), ratificado por Ley $\mathrm{N}^{\circ} 17.510$ del 27.6.2002. Artículo 5.1. La competencia de la Corte se limitará a los crímenes más graves de trascendencia para la comunidad internacional en su conjunto. La Corte tendrá competencia, de conformidad con el presente Estatuto, respecto de los siguientes crímenes... b) Los crímenes de lesa humanidad; Artículo 11.1. La Corte tendrá competencia únicamente respecto de crímenes cometidos después de la entrada en vigor del presente Estatuto. 2. Si un Estado se hace Parte en el presente Estatuto después de su entrada en vigor, la Corte podrá ejercer su competencia únicamente con respecto a los crímenes cometidos después de la entrada en vigor del presente Estatuto respecto de ese Estado, a menos que éste haya hecho una declaración de conformidad con el párrafo 3 del artículo 12. Art.20.1. Salvo que en el presente Estatuto se disponga otra cosa, nadie será procesado por la Corte en razón de conductas constitutivas de crímenes por los cuales ya hubiere sido condenado o absuelto por la Corte. Art.22.1. Nadie será penalmente responsable de conformidad con el presente Estatuto a menos que la conducta de que se trate constituya, en el momento en que tiene lugar, un crimen de la competencia de la Corte. 2. La definición de crimen será interpretada estrictamente y no se hará extensiva por analogía. En caso de ambigüedad, será interpretada en favor de la persona objeto de investigación, enjuiciamiento o condena. 3. Nada de lo dispuesto en el presente artículo afectará a la tipificación de una conducta como crimen de derecho internacional independientemente del presente Estatuto. Art.24.1. Nadie será penalmente responsable de conformidad con el presente Estatuto por una conducta anterior a su entrada en vigor.

${ }^{9}$ SCJ 20/2013 Considerando III-b

${ }^{10}$ Expresa la mayoría: "Aún cuando no hubiera obstáculos para el ingreso a nuestro ordenamiento jurídico de la categoría de los delitos de lesa humanidad y de su régimen jurídico, a través de lo que dispone el artículo 72 de la Constitución, debemos plantearnos si tal ingreso puede implicar la modificación o derogación de alguna disposición constitucional expresa o de derechos también ingresados a través del 


\section{ARGUMENTOS CONTRA LA PRESCRIPCIÓN Y A FAVOR DE LA CONSTITUCIONALIDAD DE LA LEY 18.831.}

Se han intentado distintas líneas de argumentación para derrotar la tesis de la prescripción, algunas por jueces y Tribunales y otras por la Suprema Corte de Justicia, en las escasas sentencias que rechazaron la prescripción o la inconstitucionalidad, o en extensas y reiteradas discordias. Su análisis muestra variantes y una positiva evolución en la calidad de la argumentación $\left({ }^{11}\right)$.

4.1. El primer argumento es que no puede computarse el plazo de prescripción desde que se cometió cada delito y tampoco desde el 1.3.1985, porque siempre existieron obstáculos que impidieron a las victimas acceder a la justicia y a jueces y fiscales cumplir sus funciones.

Si soslayamos la imposibilidad de obtener la comparecencia de los indagados a los juzgados cuando los citaron, el primer obstáculo relevante fue la Ley $\mathrm{N}^{\circ} 15.848$, hasta que se declaró su inconstitucionalidad por sentencia SCJ 365 del 19.10.2009. Para otros, el obstáculo persistió hasta que la Corte Interamericana de Derechos Humanos dictó el 22.2.2011 la sentencia sobre el Caso Gelman. Otros entienden que el obstáculo recién se removió cuando el Poder Ejecutivo por Decreto N³22/011 de 30.6.2011 revocó por razones de ilegitimidad los actos administrativos que habían declarado muchos casos comprendidos en la Ley de Caducidad o se promulgó la Ley No.18.831 de 27.10.2011, que reactivó la pretensión punitiva del Estado.

Es principio general indiscutido que no corre plazo de prescripción mientras quien tiene un derecho -pedir la tutela judicial- o tiene que ejercitar su función como juez o fiscal está, legalmente o de hecho, impedido de ejercitar ese derecho o función. Por esas razones nunca pudo completarse el tiempo exigido para prescribir.

\subsection{El segundo argumento refiere a casos de desaparición forzada.}

$\mathrm{Si}$ bien ese delito fue tipificado en el derecho penal nacional por Ley $\mathrm{N}^{\circ} 18.026 \mathrm{de}$ 25.9.2006, se lo calificó como “delito permanente”, por lo que, según posición consolidada en la dogmática y jurisprudencia uruguaya, debe entenderse que continúa consumándose mientras persista la desaparición, o sea, mientras no aparezca la persona o sus restos $\left({ }^{12}\right)$. De modo que al entrar en vigencia esa ley persiste la conducta delictiva y ningún plazo ha corrido.

En su discordia en la sentencia SCJ 1501/2011 de 6.5.2011, el Ministro Dr. Van Rompaey destaca que el caso en examen encuadra en la tipificación de la Ley $\mathrm{N}^{\circ} 18.026$, enfatizando la singularidad y gravedad del ilícito: "los hechos incriminados en autos no se ajustan típicamente a la figura delictiva del homicidio, en razón de que la singularidad de tal imputación no considera la multiplicidad de bienes jurídicos lesionados, que no se limitan a la privación de libertad del detenido y a su ejecución clandestina, al vulnerarse los derechos de los familiares de las víctimas, a la convivencia civilizada en sociedad, a

art.72 de la Constitución..." "el ingreso de los delitos de lesa humanidad sólo puede tolerarse con el límite impuesto por el principio de legalidad y el de irretroactividad, ambos derivados del derecho a la libertad y a la seguridad jurídica"

${ }^{11}$ Notoriamente, el Juzgado Letrado en lo Penal de $7^{\circ}$ Turno, el Tribunal de Apelaciones en lo Penal de Primer Turno. y los Ministros de la Suprema Corte Dres. Van Rompaey, Pérez Manrique, Cardinal, Hounie, Minvielle. 
la seguridad jurídica y a las bases esenciales del estado de Derecho”. La excepcional gravedad de la conducta hace que sea un delito pluriofensivo... “... constituye una violación múltiple y continuada de varios derechos de la Convención, pues no sólo produce una privación arbitraria de la libertad, sino que pone en peligro la integridad personal, la seguridad y la propia vida del detenido. Además, coloca a la víctima en estado de completa indefensión, acarreando otros delitos conexos" y también agrede a sus allegados, porque incluso "la hostilidad del Estado hacia los familiares, constituye un "tratamiento inhumano" en el sentido del art. 3 de la Convención Europea de Derechos Humanos y del art. 5.2 de la Convención Americana de Derechos Humanos". A lo que cabe agregar que la participación estatal y el proceder metódico del Estado de suspender toda protección legal al desaparecido, configura a la vez, la lesión a bienes jurídicos colectivos. Todo lo que, indudablemente, continúa en el tiempo mientras dure la desaparición.

También el Tribunal de Apelaciones en lo Penal de Primer Turno sostuvo entonces que "la inexistencia de la consagración del delito hasta el 25 de setiembre de 2006, desde cuando rige la ley 18.026, no contradice este precepto... -refiere al art.15 del Código Penal-... ni tampoco los principios fundamentales del derecho penal, principalmente el de legalidad (nullum crime sine legge). Y esto es así, porque la desaparición forzada es y se trata como un delito permanente. Este carácter asignado al delito, acarrea efectos particulares sobre su aplicación temporal. El art. 119 del CP señala que para ellos, la prescripción comienza a partir del día en que cesó la permanencia; o sea, cuando se produce la terminación de la situación antijurídica, constituida en el caso, por el voluntario ocultamiento (conducta o modalidad omisiva) del paradero de los detenidos" $\left.{ }^{(13}\right)$.

4.3. El tercer argumento sostiene que la sentencia dictada por la Corte Interamericana de Derechos Humanos el 24.2.2011 en el Caso Gelman vs.Uruguay, condenó al Estado Uruguayo, entre otras obligaciones de hacer y de no hacer, a "garantizar que la Ley de Caducidad de la Pretensión Punitiva del Estado.. no vuelva a representar un obstáculo para la investigación de los hechos materia de autos y para la identificación y, si procede, sanción de los responsables de los mismos, de conformidad con los párrafos 253 y 254 de la Sentencia"

Esa referencia a los párrafos 253 y 254 remite a lo dicho allí: “... el Estado deberá asegurar que (la Ley de Caducidad) no vuelva a representar un obstáculo para la investigación de los hechos materia del presente caso ni para la identificación y, si procede, sanción de los responsables de los mismosy de otras graves violaciones de derechos humanos similares acontecidas en Uruguay" (253) y "En consecuencia, el Estado debe disponer que ninguna otra norma análoga, como prescripción, irretroactividad de la ley penal, cosa juzgada, ne bis in idem o cualquier excluyente similar de responsabilidad, sea aplicada... "(254).

${ }^{12}$ En la Ley $\mathrm{N}^{\circ}$ 18.026, la desaparición forzada de personas se tipifica como "El que de cualquier manera $y$ por cualquier motivo, siendo agente del Estado o sin serlo contando con la autorización, apoyo o aquiescencia de uno o más agentes del Estado, procediere a privar de libertad a una persona, seguido de la negativa a informar sobre la privación de libertad o el paradero o la suerte de la persona privada de libertad; o que omita y se niegue a brindar información sobre el hecho de la privación de libertad de una persona desaparecida, su paradero o suerte" (art.21.1), aclarandose expresamente que "El delito de desaparición forzada será considerado como delito permanente, mientras no se establezca el destino o paradero de la víctima" (art.21.2).

${ }^{13}$ TAP 1, sentencia 250/2011 de 28.7.2011. CIDH, Caso Velazquez Rodríguez 
Interpretando el alcance de la mención de “otras graves violaciones de derechos humanos similares acontecidas en Uruguay" el Prof.Risso y también la propia CIDH en su Resolución del 20.3.2013 de "Supervisión de cumplimiento de la sentencia dictada en el Caso Gelman vs. Uruguay" entienden que la sentencia ordena a fiscales y jueces, que obviamente integran el Estado, que investiguen, juzguen y sancionen a los responsables de otras graves violaciones de derechos humanos que ocurrieron y les prohibe admitir eximentes de responsabilidad, entre otras, la prescripción $\left({ }^{14}\right)$.

En ese enfoque, la Ley $\mathrm{N}^{\circ} 18.831$ no cambia nada y no interesa si es o no constitucional, se trata de cumplir un fallo que es cosa juzgada y cuyo incumplimiento irroga responsabilidad internacional al Estado uruguayo. Asi lo ha entendido y cumplido en caso similar la Corte Suprema de la Nación Argentina $\left({ }^{15}\right)$. Observa el Prof. Risso que es llamativo que, mientras muchos magistrados lo han entendido, continúan investigando y rechazan la prescripción, la Suprema Corte no se entiende obligada por el fallo a actuar del mismo modo. Para este constitucionalista, la Suprema Corte debe rechazar la prescripción de esos delitos con fundamento en el fallo de la Corte Interamericana, en lugar de declarar inconstitucional la Ley 18.831, que no innova al respecto

Cabe destacar que en este argumento no está en juego el tema de la vinculatoriedad de los precedentes, que critica nuestra SCJ en la sentencia 20/2013, porque no se trata de seguir un precedente sino de cumplir derechamente un fallo internacional de condena que es cosa juzgada.

4.4. En ocasiones, para evitar la excepción de inconstitucionalidad, algunos jueces optan por rechazar la prescripción sin invocar la Ley $\mathrm{N}^{\circ} 18.831$ y los Tribunales de Apelaciones en lo Penal confirman de igual modo, lo que ha llevado a veces a que la Suprema Corte de Justicia por mayoría, declare la inadmisibilidad de la excepción de inconstitucionalidad porque no se verifica el supuesto que habilita a oponerla, según lo previsto por el art.258 de la Constitución ( $\left.{ }^{16}\right)$.

${ }^{14}$ RISSO FERRAND, Martín. "Cumplimiento de la sentencia de la Corte Interamericana de Derechos Humanos en el caso Gelman. Después de la declaración de inconstitucionalidad de la Ley Interpretativa 18.831” en Anuario de Derecho Constitucional Latinoamericano Año XIX Bogotá, 2013, p.639-653.

${ }^{15}$ El TAP 1 en sentencia 426/2017 releva la decisión de la Corte Suprema de Justicia Argentina en un caso como el presente: la justicia nacional había declarado la prescripción del delito y la CIDH dictó una sentencia similar a la del Caso Gelman. Entonces, la Corte Suprema entendió aunque ese fallo agraviara derechos fundamentales del reo, protegidos por el Pacto de San José de Costa Rica, se debía cumplir la obligación de acatarlo y continuar el proceso. Observó que "se plantea la paradoja de que sólo es posible cumplir con los deberes impuestos al Estado argentino por la jurisdicción internacional en materia de derechos humanos restringiendo fuertemente los derechos de defensa y a un pronunciamiento en un plazo razonable, garantizados al imputado por la Convención Americana. Dado que tales restricciones, empero, fueron dispuestas por el propio tribunal internacional a cargo de asegurar el efectivo cumplimiento de los derechos reconocidos por dicha Convención, a pesar de las reservas señaladas, es deber de esta Corte, como parte del Estado argentino, darle cumplimiento en el marco de su potestad jurisdiccional...” “...el fallo de la Corte Interamericana soluciona la colisión entre los derechos del imputado a una defensa amplia y a la decisión del proceso en un plazo razonable -íntimamente vinculado con la prescripción de la acción penal como uno de los instrumentos idóneos para hacer valer ese derecho...” (Ochs, Daniel. "El fallo de la Corte Interamericana de Derechos Humanos Gelman contra Uruguay" en Estudios Jurídicos N`9/2011, Montevideo, UCUDAL, 2011, p. 104).

${ }^{16}$ El citado art.258 regula la legitimación activa y establece que "La declaración de inconstitucionalidad de una ley y la inaplicabilidad de las disposiciones afectadas por aquélla, podrán solicitarse por todo aquel que se considere lesionado en su interés directo, personal y legítimo" por dicha ley. El argumento lo 
4.5. Otra línea de argumentación, que ha ocupado un lugar central en la discusión y ha sido especialmente resistida por la mayoría en nuestra Suprema Corte, sostiene que cuando ocurrieron esas conductas ya eran calificadas por el derecho internacional como "crímenes de lesa humanidad" y ya estaba dispuesto que debían ser investigadas y sus responsables sancionados $\left({ }^{17}\right)$.

La tesis es que los actos cometidos por la dictadura no pueden ser juzgados desde la óptica del derecho penal nacional, sino que corresponde aplicar la normativa supranacional, no debería ser ignorada por ningún tribunal nacional porque son normas de "orden público internacional" (ius cogens) y estaban en vigencia antes de que se cometieran las atrocidades que tuvieron lugar en Uruguay entre.1968y1985 (18), por lo cual, Uruguay no puede dejar de investigar y juzgar aunque el derecho nacional disponga otra cosa.

Por demás, como se trata de proteger y garantizar derechos inherentes a la personalidad humana, debe entenderse que esas normas siempre fueron obligatorias entre nosotros por el art.72 de nuestra Constitución y es precisamente el art.72 el que impide la prescripción de esos delitos.

La razón por la que la comunidad Internacional considera que esos actos son crímenes, aún si no lo fueran para el orden juridico estatal, es porque agreden la humanidad de las personas a la que es preciso proteger del modo más eficaz. Por eso tales crímenes deben ser investigados y castigados sin que pueda oponerse amnistía ni prescripción, ni cosa juzgada nacional, ni ningún otro obstáculo.

Como esto es especialmente discutido, requiere una justificación más detallada, explicitando y completando lo dicho en las discordias.

4.5.1. Un poco de historia no muy reciente. Para empezar, como señala el Ministro Dr. Pérez Manrique en su discordia a la sentencia SCJ 20/2013 de 22.2.2013, es posible reconstruir un hilo histórico relevante desde el final de la Segunda Guerra Mundial, que empieza en 1945 en el Acuerdo de Londres, con la aprobación del Estatuto de los Tribunales de Nuremberg y Tokio.

En efecto, el 8.8.1945 el Acuerdo de Londres dispuso constituir Tribunales Militares Internacionales para enjuiciamiento y castigo de los principales crímenes de guerra cometidos por el Eje y aprobó una Carta de Constitución y un Estatuto para esos Tribunales. El 12.11.1945 Uruguay, por decisión del Poder Ejecutivo, según lo aconsejado por el Comité Jurídico Interamericano reunido en Rio de Janeiro a mediados de ese año, adhirió al Acuerdo de Londres $\left({ }^{19}\right)$. El 11.12.1946, la Asamblea General de ONU, por resolución 95/1946 resolvió "confirmar los principios de Derecho Internacional reconocidos por el Estatuto del

introducen los Ministros Pérez Manrique y Minvielle en la sentencia SCJ 382/2014 de 7.4 .2014 y se convierte en posición aceptada por mayoría desde la sentencia SCJ 794/2014 de 4.9.2014, seguida también por el Ministro Larrieux, en otras sentencias como SCJ 878/2014, SCJ N 1061/2015, 10/2016 y 124/2016.

${ }^{17}$ Esos crímenes de Derecho Internacional son de tres tipos: crímenes contra la paz, crímenes de guerra y crímenes contra la humanidad y estos últimos incluyen asesinato, exterminio, esclavización, deportación $\mathrm{u}$ otros actos inhumanos cometidos contra población civil y la persecución que, por motivos políticos, raciales o religiosos, se lleve a cabo en relación con delitos contra la paz o crímenes de guerra.

${ }_{18}$ Periodo señalado por Ley $\mathrm{N}^{\circ} 18.596$ de 18.9.2009

${ }^{19}$ Ese Comité Jurídico Interamericano existía desde 1942, como sucesor de la Comisión Permanente de Jurisconsultos, con sede en Rio de Janeiro y el 30.7.1945 emitió su dictamen sobre La condición jurídica internacional de los criminales de guerra . 
Tribunal de Nuremberg y las sentencias de dicho Tribunal” y en 1950, aprobó un documento recogiendo esos "Principios de Derecho Internacional reconocidos por el Estatuto y por las sentencias del Tribunal de Núremberg” donde se señala especialmente que "El hecho de que el derecho interno no imponga pena alguna por un acto que constituya delito de derecho internacional no exime de responsabilidad en derecho internacional a quien lo haya cometido".

De modo que desde entonces existen crímenes contra la humanidad que deben ser juzgados y castigados, aún si no fueran delitos para el ordenamiento penal nacional respectivo. Siguen la Convención para la Prevención y Sanción del Delito de Genocidio (1948) declarado también "delito de derecho internacional” y que los Estados deben prevenir y sancionar, y los Convenios de Ginebra (1949) que establecen que los Estados "se comprometen a tomar todas las oportunas medidas legislativas para determinar las adecuadas sanciones penales que se han de aplicar a las personas que hayan cometido, o dado orden de cometer, una cualquiera de las infracciones graves... como atentados contra la vida, mutilaciones, toma de rehenes, tortura, tratos humillantes, crueles y degradantes". Uruguay ratificó ambos instrumentos, la primera en 1967 y los segundos en 1969 o sea antes de los hechos que se juzgan hoy.

Por lo que a fines de la década del sesenta no podía caber duda de que determinados actos eran delitos de derecho internacional -crímenes de lesa humanidad- y que la comunidad internacional exigía a los Estados impedirlos y si no, investigar, juzgar y sancionara los responsables.

La seriedad del argumento planteado por el Ministro Dr. Pérez Manrique requería que la mayoría diera alguna buena razón, si la hubiera, para dejar de lado ese contexto histórico y jurídico que parece incuestionable y según el cual no es aceptable argumentar que los delitos de lesa humanidad recién fueron creados por el derecho uruguayo con posterioridad al 1.3.1985.

Siguiendo el hilo histórico cabría agregar que durante la dictadura, en momentos de dura represión, por Decreto-ley 14.728 de 28.11.1977, Uruguay ratificó la Convención Interamericana para prevenir y sancionar los Actos de Terrorismo (1971), asumiendo la obligación de tomar todas las medidas necesarias "para prevenir y sancionar los actos de terrorismo y en especial, el secuestro, el homicidioy otros atentados contra la vida y la integridad de las personas a quienes el Estado tiene el deber de extender protección especial conforme al Derecho Internacional, así como la extorsión conexa con estos delitos"(art.1). La Convención también dispone que "toda persona privada de su libertad por aplicación de la presente Convención gozará de las garantías del debido proceso"(art.4) y debe garantizársele "el más amplio derecho de defensa" (art.8 lit.c).

La interpretación sesgada que el gobierno de facto pudo hacer de esta Convención desde el marco de la nefasta doctrina de la seguridad nacional, restringiendo el concepto de terrorista a toda persona no grata al régimen $\left({ }^{20}\right)$, no deja de mostrar que ni siquiera cumplió su obligación de respetar el debido proceso y el derecho de defensa de quienes eran acusados.

${ }^{20}$ CHOMSKY, Noam. Piratas y emperadores: terrorismo internacional en el mundo de hoy. Barcelona, Marcial Pons, 2004. El autor observa el uso de los términos como expresión del poder de nombrar de quien habla y precisamente lo ejemplifica con el término "terrorismo". 
Huelga decir que además incumplió la Convención porque incurrió en todos los actos descriptos como terrorismo, como han reconocido gobiernos constitucionales posteriores, tácitamente por el hecho de aprobar la Ley $\mathrm{N}^{\circ} 15.848$ para asegurar la impunidad de los militares y policías y explicítamente al dictar la Ley $\mathrm{N}^{\circ} 18.596$ de 18.9.2009 en la que admite que hubo "terrorismo de Estado" $\left({ }^{21}\right)$.

Tampoco los gobiernos constitucionales siguientes cumplieron su deber de "sancionar los actos de terrorismo y en especial, el secuestro, el homicidio y otros atentados contra la vida y la integridad de las personas", ocurridos bajo la vigencia de las normas internacionales que ya habían sido ratificadas y tras el conocimiento cabal de la práctica sistemática de terrorismo de Estado en el período precedente.

Además, en 1968 se había aprobado la Convención Internacional sobre la Imprescriptibilidad de los Crímenes de Guerra y de los Crímenes de Lesa Humanidad, que incorporaba una norma consuetudinaria declarando imprescriptibles esos crímenes, cualquiera que sea la fecha en que se hayan cometido. Si bien Uruguay la ratificó recién por Ley $\mathrm{N}^{\circ}$ 17.347 de13.6.2001, su ratificación no era necesaria para aplicarla por la razón que se explica seguidamente y, una vez que la ratificó, tenía el deber de investigar y sancionar esos crímenes cualquiera que sea la fecha en que se hubieran cometido.

4.5.2. El concepto de orden público internacional (ius cogens). Es preciso recodar que el derecho internacional de los derechos humanos pretende obligatoriedad universal que se impone sobre cualquier orden jurídico nacional que disponga otra cosa.

Se sostiene que integra un conjunto de normas que califican como de "orden público internacional" o ius cogens, del que ningún Estado puede apartarse.

El Prof. SANCHEZ PATRON lo explica de este modo: "Para los órganos internacionales no hay duda de que determinadas prácticas con las que se ponen en peligro o se conculcan los derechos humanos son inadmisibles. La prohibición de los actos que conforman los crímenes contra la humanidad tienen la consideración de normas de ius cogens. Esto significa que esta norma singular no admite disposición normativa en contrario (excepto las que fuesen del mismo carácter), lo que explica que la legislación nacional que sea contraria a la misma deba considerarse nula ab initio. Asimismo, las normas de ius cogens se caracterizan por el hecho de que de las mismas se derivan obligaciones erga omnes, lo que permite extraer como consecuencia el que terceros estén facultados para actuar con ocasión de la trasgresión de este tipo de normas internacionales. Esta facultad no sólo es extensible a terceros Estados sino a los propios particulares, a los que se les legitima para exigir el esclarecimiento de prácticas prohibidas y el castigo de los que hayan participado en las mismas" $\left.{ }^{(22}\right)$.

${ }^{21}$ Ley 18.596 de 18.9.2009. Artículo $1^{\circ}$.- Reconócese el quebrantamiento del Estado de Derecho que impidiera el ejercicio de derechos fundamentales a las personas, en violación a los Derechos Humanos o a las normas del Derecho Internacional Humanitario, en el período comprendido desde el 27 de junio de 1973 hasta el 28 de febrero de 1985 . Artículo $2^{\circ}$.- Se reconoce la responsabilidad del Estado uruguayo en la realización de prácticas sistemáticas de tortura, desaparición forzada y prisión sin intervención del Poder Judicial, homicidios, aniquilación de personas en su integridad psicofísica, exilio político o destierro de la vida social, en el período comprendido desde el 13 de junio de 1968 hasta el 26 de junio de 1973, marcado por la aplicación sistemática de las Medidas Prontas de Seguridad e inspirado en el marco ideológico de la Doctrina de la Seguridad Nacional.

${ }^{22}$ SANCHEZ PATRON, José Manuel, Trabajo citado "La imprescriptibilidad de los crímenes contra la humanidad en Uruguay" en Revista de la Facultad de Derecho (UDELAR) $N^{\circ} 25$, p. 
El concepto es recogido por la Convención de Viena sobre Derecho de los Tratados (1969) según la cual existen "normas imperativas de derecho internacional" aceptadas y reconocidas por la comunidad internacional "como normas que no admiten acuerdo en contrario y que sólo puede ser modificada por una norma ulterior de derecho internacional general que tenga el mismo carácter"(art.53). Expresamente se acuerda la prohibición de "invocar las disposiciones de su derecho interno comojustificación del incumplimiento de un tratado" (art.27). Esa Convención Internacional fue ratificada por Uruguay por Decreto-Ley $N^{\circ} 15.195$ de 10.10.1981, esto es, durante el gobierno de facto y es regularmente invocado por la doctrina y por la Corte Interamericana de Derechos Humanos.

Aplicando el concepto a esta materia, el Prof.Héctor Gros Espiell decía que "el deber de respetar los derechos del hombre constituye una norma imperativa de derecho internacional general, un caso de jus cogens, quizás el más característico de nuestra época, con todas las consecuencias que de esta afirmación se derivan, cuyo respeto y vigilancia se vinculan con la idea de "orden público internacional” lo que implica también efectos de obvia importancia” $\left.{ }^{23}\right)$

Para confirmar que por imperio del ius cogens internacional ciertos delitos califican como lesivos para la humanidad y son imprescriptibles, basta una rápida mirada a la jurisprudencia de los tribunales internacionales, en particular, las sentencias de la Corte Interamericana de Derecho Humanos. Así, en la sentencia del 26.9.2006, del caso Almonacid Arellano vs. Chile se invoca el ius cogens para exigir a Chile que investigue y sancione los crímenes de lesa humanidad cometidos durante la Operación Condor, rechazando expresamente el argumento sobre la prescriptibilidad planteado por el Estado demandado. También en la sentencia del 22.9.2009, del Caso Anzualdo Castro vs. Perú, juzgando sobre una desaparición forzada, la Corte recuerda que "en su jurisprudencia constante sobre este tipo de casos ... ha reiterado que la desaparición forzada de personas constituye una violación múltiple de varios derechos protegidos... particularmente grave cuando forma parte de un patrón sistemático o práctica aplicada o tolerada por el Estado..”y como tal, “dada la particular gravedad de las transgresiones que conlleva y la naturaleza de los derechos lesionados... implica un craso abandono de los principios esenciales en que se fundamenta el sistema interamericano y cuya prohibición ha alcanzado el carácter de jus cogens..."

En la misma sentencia, la Corte Interamericana aclara que la imprescriptibilidad de esos delitos no surge con la Convención Internacional aprobada en 1968 sino que "está reconocida en ella” como norma consuetudinaria de ius cogens que data de tiempo atrás ${ }^{(24)}$. También el reconocido penalista R. Zaffaroni, Ministro de la Corte Suprema de la

${ }^{23}$ GROS ESPIELL, Héctor. Estudios sobre derechos humanos, Caracas, Ediciones del IIDH, 1985, p. 298

${ }^{24}$ STEINER, Christian y URIBE, Patricia. "Introducción general” en la obra colectiva compilada por ambos Convención Americana sobre Derecho Humanos. Comentario, Argentina, Konrad Adenauer Stiftung, 2014, dicen que "La costumbre legal internacional son las obligaciones internacionales de los Estados que no se encuentran escritas y se compone de dos elementos: una práctica estatal consistente y uniforme, y la opinio juris, que es la creencia de que existe una obligación legal para seguir esa práctica. Algunos derecho humanos esenciales son obligatorios para los Estados por formar parte del derecho consuetudinario internacional, esto se traduce en obligaciones directas para los Estados aún cuando el Estado no haya ratificado el instrumento internacional que reconoce ese derecho". 
Nación Argentina ha consignado que la Convención “...se limita a codificar como tratado lo que antes era ius cogens en función del derecho internacional público consuetudinario, siendo materia pacífica que en esta rama jurídica, la costumbre internacional es una de sus fuentes. En consecuencia, la prescripción establecida en la ley interna no extinguía la acción penal con anterioridad a esa ley y, por tanto, su ejercicio en función de la misma no importa una aplicación retroactiva de la ley penal" $\left({ }^{25}\right)$. Al ratificar esa Convención sin reserva alguna -reitero- Uruguay se obligó a perseguir esos crímenes "cualquiera que sea la fecha en que se hayan cometido". Ese criterio ha sido aceptado y cumplido por Cortes Supremas de varios Estados del sistema interamericano, entre otras, la Corte Argentina en sentencia de 13.7.2007 del Caso Mazzeo $\left({ }^{26}\right)$ y de la Corte Suprema de Justicia de Colombia - Sala Penal, en sentencia del 14.3.2011 en el de la Caso Masacre de Segovia $\left({ }^{27}\right)$.

El fundamento del valor normativo superior del ius cogens es que esas normas, se apoya en su amplia aceptación internacional y su singular valor para proteger la dignidad humana y la paz. Por eso requiere aplicación inmediata y directa por las autoridades estatales, incluyendo a los tribunales, y prevalece sobre normas nacionales de cualquier rango $\left.{ }^{28}\right)$. Por lo que, aunque no existiera el art.72 en nuestro texto constitucional, ese derecho vendría a integrar la normativa jurídica aplicable por jueces y tribunales con preferencia a la normativa de origen nacional.

Este ius cogens y su fuerza obligatoria fue reconocido por nuestra Suprema Corte en la sentencia SCJ 365/2009 en la que, citando a la Corte argentina, dijo que "las leyes de amnistía similares a la nuestra no tienen en cuenta... el carácter de jus cogens que ostentan las normas internacionales, ya sean creadas por pactos o convenciones, ya sean de carácter consuetudinario».

Esa sentencia -citando un trabajo publicado en esta Revista $\left({ }^{29}\right)$ - recordaba que, por lo menos desde 1985, es ampliamente reconocido entre nosotros el valor jurídico normativo del derecho internacional de los derechos humanos, que esas normas constituyen un "orden público internacional"y no requieren aceptación o ratificación de un Estado en particular sino que prevalecen sobre las normas nacionales de cualquier rango, siendo de aplicación inmediata y directa por las autoridades nacionales, incluyendo a los tribunales $\left.{ }^{(30}\right)$.

25 Sentencia del Caso Arancibia Clavel, citado por TAP $1^{\circ}$ Sentencia 426/2017.

26 Caso Mazzeo. http://observatoriointernacional.com/?p=1852

27 Caso Masacre de Segovia. https://corte-suprema-justicia.vlex.com.co/vid/-273744931

${ }^{28}$ El Estatuto de la Corte Internacional de Justicia, agregado a la Carta de Naciones Unidas de 26.6.1945, identifica como normas válidas de derecho internacional, aplicables para decidir las controversias, tanto las que son resultado de acuerdos internacionales aprobados por el país, como las que forman parte de la costumbre internacional o son principios generales de derecho (art.38). Las primeras referencias al ius cogens llegaron aquí en 1985 con el Prof. Héctor Gros Espiell, Director del Instituto Interamericano de Derechos Humanos, mucho antes de que, por Ley $\mathrm{N}^{\circ} 16.173$ de 30/3/91, ratificáramos la Convención de Viena sobre Derecho de los Tratados aprobada en Naciones Unidas el 23.5.1969.

${ }^{29}$ CASTRO RIVERA, Alicia, «La Ley No.15.848 y la Constitución (I). Una sentencia que no pudo clausurar el debate» en Revista de Derecho Público Número 35, Montevideo, 2009, p.125-154.

${ }^{30}$ El Estatuto de la Corte Internacional de Justicia, agregado a la Carta de Naciones Unidas de 26.6.1945, identifica como normas válidas de derecho internacional, aplicables para decidir las controversias, tanto las que son resultado de acuerdos internacionales aprobados por el país, como las que forman parte de la costumbre internacional o son principios generales de derecho (art.38). Las primeras referencias al ius cogens llegaron aquí en 1985 con el Prof. Héctor Gros Espiell, Director del Instituto Interamericano de Derechos Humanos, mucho antes de que, por Ley $\mathrm{N}^{\circ} 16.173$ de 30/3/91, ratificáramos la Convención de Viena sobre Derecho de los Tratados aprobada en Naciones Unidas el 23.5.1969. 
Actualmente, la Ministra Dra.Minvielle desarrolla particularmente el concepto en su discordia a la sentencia SCJ 680/2017 en términos que merecen reproducirse $\left({ }^{31}\right)$.

Entre nosotros, la exigencia de aplicación directa por jueces y tribunales nacionales y la preferencia que les exige un control de convencionalidad, ha suscitado entre nosotros dificultades y resistencias que apunta la sentencia SCJ 20/2013, en la que pesan el antiguo dualismo y una pretensión de soberanía nacional a ultranza.

Desde el ámbito internacional la Corte Interamericana sostiene que todos los jueces nacionales -como instituciones estatales que han de aplicar las normas protectora de los derechos humanos, sean de fuente nacional o supranacional y resolver los potenciales conflictos- deben practicar un «control de convencionalidad» del derecho nacional y cuando éste se aparta de las directivas o soluciones del derecho internacional, deben priorizar este último.

La mayoría en la sentencia SCJ 20/2013 cuestiona ese «control de convencionalidad» a cargo de los jueces $\left({ }^{32}\right)$ y también su alcance a la Constitución Nacional, afirmando derechamente la primacía del orden interno en base al principio de soberanía nacional. Sin embargo, lo dispuesto en la Constitución Nacional en sus arts.72 y 332, indica que el derecho internacional en esta materia tiene jerarquía constitucional y por ende, deben ser tenido en cuenta para juzgar la constitucionalidad de las leyes. Así que, sin necesidad de definir si el ius cogens prevalece o no sobre la Constitución Nacional, basta saber que prevalece sobre las leyes que pretendan desconocerlo.

También cuestiona la sentencia SCJ 20/2013, la tesis de la Corte Interamericana de que, en materia de derechos humanos, sus propias decisiones tienen valor obligatorio más allá de los casos concretos que resuelven, como res interpretata y precedente vinculante para los casos venideros $\left({ }^{33}\right)$.

Como dije, no sería éste un caso en que se afirma el valor vinculante de un precedente, porque la Corte Interamericana entiende haber resuelto en la sentencia del Caso Gelman el rechazo de la prescripción en todos los casos y lo considera cosa juzgada. Sin embargo, es cierto que ha sostenido en varias otras sentencias, que por ser la intérprete última de la Convención Americana de Derechos Humanos, sus decisiones sobre la interpretación de los derechos en el sistema interamericano y su compatibilidad con las normas internas de los Estados partes, tienen particular valor decisorio en otros litigios en que se plantean

31 «los crímenes de lesa humanidad en tanto pueden considerarse atentados a los básicos derechos humanos universalmente aceptados son tales, no por la voluntad del Estado, ....sino por imperio de normas internacionales inderogables que constituyen el ius cogens internacional y que nos confieren la certeza de la existencia de una conciencia y convicción moral universal que va desde Nuremberg a La Haya y que proclama que ciertos delitos atentatorios de derechos humanos básicos, ejecutados en virtud de un plan y de manera generalizada, deben ser perseguidos siempre y por todos en cualquier confín de la tierra»

32 Entre nosotros, dado que todos estos derechos se consideran de jerarquía constitucional, hay quienes afirman que quien debe decidir ese conflicto es la Suprema Corte de Justicia. Hay diferencia clara entre sostener que no corresponde hacer un control de convencionalidad del derecho nacional y reclamar la competencia exclusiva para decidir eventuales conflictos entre derechos fundamentales que tienen jerarquía constitucional.

${ }^{33}$ FERRER MAC GREGOR, Eduardo. «Eficacia de la sentencia interamericana y la cosa juzgada internacional: vinculación directa hacia las partes (res judicata)e indirecta hacia los Estados parte de la convención americana (res interpretata). Sobre el cumplimiento del Caso Gelman vs.Uruguay» en Anuario de Derecho Constitucional Latinoamericano Año XIX Bogotá, 2013, p.607-638. 
cuestiones similares $\left({ }^{34}\right)$. Siendo la única instancia jurisdiccional en el sistema, es claro que su interpretación de la Convención tiene alto valor como precedente en el sistema regional y su consulta no puede ser soslayada al momento de analizar y decidir sobre el mejor modo de interpretar los derechos humanos porque constituyen una guía inestimable por su amplia experiencia y alta calidad técnica y también teniendo en cuenta que tiene la última palabra en esta materia. Esto no significa que se deban seguir de modo acrítico tales precedentes, cualquier órgano jurisdiccional tiene reconocida su independencia de criterio y está habilitado para disentir y apartarse del precedente -aún siendo vinculante- pero el apartamiento de precedentes prestigiosos exige una carga argumentativa que es preciso satisfacer y no se satisface negando genéricamente la relevancia de los precedentes.

\subsubsection{No existe conflicto entre el Derecho Internacional de los Derechos Humanos y nuestra Constitución Nacional.}

En nuestro país no puede plantearse conflicto entre el Derecho Internacional de los Derechos Humanos y nuestra Constitución Nacional.

Doctrina y jurisprudencia, incluso de la Corte $\left({ }^{35}\right)$, admiten que el art.72 de la Carta asegura la sintonía entre el orden constitucional y el derecho internacional de los derechos humanos y permite admitir la jerarquía constitucional todos los derechos y garantías que éste último reconoce.

Si el problema consiste en armonizar la normativa de uno u otro origen, se ha identificado algunos criterios para orientar la tarea del intérprete o aplicador: principios, de complementariedad y progresividad delos derechos, además del criterio pro persona, que prioriza la norma que mejor protege el derecho en el caso. Sin embargo, en casos como el que resuelve la SCJ, el criterio es lisa y llanamente la exclusión del derecho nacional contrario al derecho internacional y eso está muy claro desde el Estatuto de Nuremberg hasta la Convención de Viena.

Y entre nosotros no sólo es la solución desde el derecho internacional sino que también es la solución constitucional, debido al art.72 y en razón de que se trata de garantizar derechos fundamentales reconocidos.

La mayoría -que empezó planteado unicamente el derecho de los indagados a la prescripción de sus delitos, sin mencionar derechos de las víctimas-finalmente asume que hay un conflicto de orden constitucional y lo resuelve mal, a mi juicio. No se ve cómo la armonización entre el hipotético derecho de los indagados y el derecho de las víctimas pueda terminar, sin darse una sola razón, priorizando el primero y sacrificando completamente el segundo $\left({ }^{36}\right)$.

${ }^{34} \mathrm{La}$ CIDH sostiene ese criterio desde la Opinión Consultiva 7/1986, basandose en el art.2 de la Convención Americana de Derechos Humanos. Para verlo más ampliamente, remito al trabajo recién citado de FERRER MAC GREGOR, p. 621-628.

35 SCJ Sentencia 365/2009.

${ }^{36}$ Expresa la mayoría: "Aún cuando no hubiera obstáculos para el ingreso a nuestro ordenamiento jurídico de la categoría de los delitos de lesa humanidad y de su régimen jurídico, a través de lo que dispone el artículo 72 de la Constitución, debemos plantearnos si tal ingreso puede implicar la modificación o derogación de alguna disposición constitucional expresa o de derechos también ingresados a través del art.72 de la Constitución...» «el ingreso de los delitos de lesa humanidad sólo puede tolerarse con el límite impuesto por el principio de legalidad y el de irretroactividad, ambos derivados del derecho a la libertad y a la seguridad jurídica» 
Entre nosotros, un eventual conflicto como el que plantea la mayoría, sería, en todo caso, un conflicto entre derechos fundamentales de rango constitucional. De acuerdo con la dogmática constitucional, una situación de tensión o conflicto entre derechos de rango constitucional, un desacuerdo acerca de cuál ha de prevalecer y en qué medida, consiste, en puridad, en un problema de interpretación constitucional o, en último caso, de balance entre derechos.

Lo cierto es que ni siquiera existe conflicto entre derechos desde que el derecho internacional de los derechos humanos tiene resuelto que no hay derecho a la prescripción de los crímenes de lesa humanidad. En otras palabras, ante una duda sobre un hipotético conflicto, la normativa supranacional establece el criterio para resolver el dilema del decisor: prevalece el derecho a la tutela judicial efectiva de las víctimas y no existe ningún derecho del eventual responsable de crímenes de lesa humanidad a la prescripción del delito.

Comentando el tema, expresa el Prof. Sánchez Patrón que "considerar prescritas las acciones que hubieran podido ejercitarse en relación con unos hechos delictivos, sólo se justifica en aras de la seguridad jurídica de los sujetos afectados por las mismas, ya que no se les puede obligar a dichos sujetos a responder de los hechos delictivos después de que haya transcurrido un periodo de tiempo considerable desde su comisión. Ahora bien, esta concepción y finalidad de la institución de la prescripción no resulta aplicable a los hechos ocurridos durante el llamado "periodo de facto" $\left({ }^{37}\right)$

En la misma línea, la Dra.Minvielle en su discordia recuerda que la prescripción de los no se puede calificar como un derecho fundamental porque nada tiene que ver con proteger derechos humanos. Es un instituto del derecho penal interno que responde a razones muy distintas -de oportunidad y conveniencia de terminar una situación que no se resuelve- y es precisamente por eso que el derecho de la comunidad internacional no la admite para delitos de la mayor gravedad, como son los delitos de lesa humanidad $\left({ }^{38}\right)$.

\section{ANÁLISIS CRÍTICO DE LA ARGUMENTACIÓN.}

Desde las exigencias de las teorías de la argumentación jurídica racional, una decisión jurídica debe estar justificada por un razonamiento lógicamente correcto a partir de premisas que, a su vez, han sido aceptadas o correctamente justificadas. Por locuales necesario -en primer lugar- mostrar que el fallo se infiere de las premisas seleccionadas y luego, dar cuenta también de las razones de la elección de esas premisas, como presupuestos de la mejor decisión posible según el derecho vigente y aplicable al caso a resolver.

5.1. El primer problema que advierto es que la mayoría declara la inconstitucionalidad del artículo 2 de la Ley 18.831, que impide computar plazo de prescripción o caducidad entre el 22.12.1986 y el 11.11.2011, sin dar ninguna razón.

${ }^{37}$ SANCHEZ PATRON, José Manuel «La imprescriptibilidad de los crímenes contra la humanidad en Uruguay» en Revista de la Facultad de Derecho (UDELAR) N 25, Montevideo, FCU, 2006, p.261-286.

${ }^{38}$ Señala la Ministra Dra. Minvielle en su discordia que «la prescripción de los crímenes no constituye un derecho esencial de las personas... constituye una práctica de oportunidad convertida en norma ...» citando un trabajo de Graven "Les crimes contre l'humanité peuvent-ils benéficiérs de la prescription?" en Revue Penale Suisse, T. 81 
Si bien este artículo 2 es claramente inconsistente con la imprescriptibilidad declarada por el artículo $3\left({ }^{39}\right)$, si se rechaza la imprescriptibilidad, es necesario justificar por qué la suspensión del plazo durante el tiempo en que el ejercicio de la pretensión punitiva estuvo impedido por la vigencia de la Ley de Caducidad sería violatoria de la Constitución. La suspensión del plazo no colide necesariamente con los principios de legalidad e irretroatividad de la ley penal invocados contra el art. $3\left({ }^{40}\right)$.

5.2. En segundo lugar, en una argumentación racional no es admisible sustentar la decisión en premisas normativas que son irrelevantes o falsas, excluyendo otras que debieron ser tenidas en cuenta de modo principalísimo

Como se dijo, la cuestión a resolver es si los delitos indagados son o no «crímenes de lesa humanidad»y, por tanto, imprescriptibles.

La mayoría elige plantear la discusión desde un tópico o lugar que supuestamente le permitiría justificar su decisión: recorta la normativa aplicable tomando sólo el derecho nacional, sostiene que según nuestro Código Penal existe un derecho a la prescripción de cualquier delito e, invocando el artículo 10 del texto constitucional, del que infiere los principios de legalidad e irretroactividad de la ley penal, considera que la imprescriptibilidad vulnera un derecho fundamental.

Hay ahí dos falacias. La primera es afirmar que el universo normativo a considerar es unicamente el Código Penal Uruguayo y los principios de legalidad e irretroactividad. El texto constitucional por el art.72 remite al derecho internacional de los derechos humanos e impone otro enfoque normativo, que incluye toda la normativa internacional protectora de los derechos reconocidos a las personas en razón del valor atribuido a la condición humana. En ese universo normativo la imprescriptibilidad de los delitos que los agreden no vulnera el principio de legalidad ni de irretroactividad de la ley penal porque para los crímenes que el orden internacional califica como de lesa humanidad la imprescriptibilidad estaba prevista desde antes de 1968. Por lo cual esos principios no son relevantes en este problema, no hay ninguna violación a ellos.

La segunda falacia es que con tales principios se pretende proteger a las personas contra la posibilidad deimponerles penas por conductas que eran lícitas cuando se realizaron, locual no aplica en este caso. Como observaba el Ministro Dr. Van Rompaey en la sentencia SCJ 1501/2011 y reitera la Ministra Dra. Minvielle en su discordia a esta sentencia SCJ 680/2017, no se penalizan conductas que en aquel momento eran lícitas, sino que $a b$ initio encuadraban en figuras delictivas previstas en el derecho uruguayo anterior al quiebre institucional, eran delitos graves (privación de libertad, homicidio, lesiones, violación, atentado violento al pudor, entre otros) y tampoco se les aumenta la pena que les correspondía según las leyes vigentes. La mayoría adopta, a sabiendas, una premisa falsa $\left({ }^{41}\right)$.

${ }^{39}$ Hay indudable inconsistencia entre los arts.2 y 3. Si se admite la imprescriptibilidad (art.3), es contradictorio lo dispuesto en el art. 2 y podría ser considerado inconstitucional en la medida en que permite interpretar que, para los delitos comprendidos en el artículo 1, si bien no se computa plazo de prescripción por el período 22.12.1986 a 26.10.2011, podría computase luego de esa fecha. Esta contradicción de la ley fue también señalada por la Dra. Mariana Mota en su comentario «Crímenes de lesa humanidad, imprescriptibilidad, irretroactividad de la ley penal» Revista de Derecho Penal 25, Montevideo, FCU, 2017 p.337-346.

${ }^{40}$ El tema del cómputo del plazo ha sido desarrollado sumariamente en el parágrafo 4.1.

${ }^{41}$ La mayoría insiste en que "es preciso que el sujeto pueda saber en el momento en que actúa si va a incurrir en algún delito o en alguna nueva pena» como si fuera posible creer que quienes llevaron 
La mayoría cita disposiciones del derecho penal nacional y retoma afirmaciones del penalista Dr. Bayardo Bengoa -destacado integrante del gobierno cívico-militar- que extienden el principio de irretroactividad a la prescripción de los delitos, sin tener en cuenta que, para la comunidad internacional que integramos desde 1945, esas conductas, insertas en un contexto de persecución terrorista por parte del Estado, eran crímenes desde el momento fundacional de la Organización de Naciones Unidas, desde el Estatuto de Nuremberg de 1945 y los Convenios de Ginebra del 12.8.1949, con aprobación de la Asamblea General de Naciones Unidas $\left({ }^{42}\right)$. No hay ninguna violación del principio de legalidad ni aplicación retroactiva de la ley penal más severa. Tales crímenes siempre se consideraron imprescriptibles y asílo declara la Convención Internacional sobre la Imprescriptibilidad de los Crímenes de Guerra y de los Crímenes de Lesa Humanidad de 1968.

En suma, no están en discusión ni el principio de legalidad ni la irretroactividad de la ley penal más severa. El discurso sobre la libertad, la seguridad jurídica, la legalidad y la irretroactividad de la ley penal resulta un ejercicio retórico destinado a evitar la investigación y sanción de hechos que bajo ninguna óptica pueden suponerse como lícitos en el momento en que se realizaron. No es correcto soslayar que, según el derecho internacional de los derechos humanos, universalmente obligatorio, los actos que se juzgan eran calificados -desde antes de que se perpetraran- como crímenes de lesa humanidad, imprescriptibles, y su investigación y el juicio a sus responsables era ya un deber de todos los Estados que integran el sistema universal y el sistema regional, sin importar el momento en que se hubieran cometido, siendo inadmisible invocar el derecho interno para incumplir ese deber $\left({ }^{43}\right)$.

5.3. Siempre desde la perspectiva de la argumentación, quisiera agregar alguna consideracion sobre la corrección jurídica de la respuesta que ofrece la mayoría como la decisión de un caso difícil, entendiendo por tal un caso que podría admitir soluciones diversas.

En tales casos el desafío es encontrar la mejor respuesta posible desde el derecho, que no sólo deberá ser consistente con el sistema jurídico vigente y aplicable al caso -y ésta no lo es- sino también coherente con los valores que ese sistema jurídico sustenta, atendiendo especialmente a las consecuencias que esa decisión pueda tener en el contexto del sistema de justicia, de quienes resultan afectados por ella y del resto de la sociedad. Como ha dicho el teórico escocés Neil MacCormick, la decisión debe tener sentido en el derecho y en el mundo $\left({ }^{44}\right)$.

adelante una represión violatoria del derecho a la vida, a la integridad física, sexual y psíquica y libertad de sus víctimas pudieran haber ignorado que sus conductas configuraban ilícitos penales

${ }^{42}$ En 1950 la Asamblea General de Naciones Unidas aprobó los «Principios de Derecho Internacional reconocidos por el Estatuto y por las sentencias del Tribunal de Núremberg»

${ }^{43} \mathrm{La}$ Convención Internacional sobre la Imprescriptibilidad de los Crímenes de Guerra y de los Crímenes de Lesa Humanidad de 1968 es especialmente clara en cuanto a que tales crímenes "son imprescriptibles, cualquiera que sea la fecha en que se hayan cometido" $\mathrm{y}$ " aun si esos actos no constituyen una violación del derecho interno del país donde fueron cometidos " (art.1) así como sobre el compromiso de los Estados partes de evitar la aplicación de la prescripción de la ación penal o de la pena en esos caso (art.4).

${ }^{44}$ Mac CORMICK, Neil. Legal reasoning and legal theory. Oxford, Clarendon Press, 1978, p.103: "...legal decisions must make sense in the world and they must be also make sens in the context of the legal system". 
En esa línea, deberíamos pensar en una decisión que represente la mejor versión del derecho y haga que nuestro mundo sea un poco mejor. Una decisión coherente con los valores y principios que representa el Derecho y cuyas consecuencias contribuyan a mostrar que el Derecho es una herramienta valiosa para proteger a la comunidad y para las personas que la integran. La visibilidad actual del sistema de justicia nos exige ser conscientes de que la legitimidad del Poder Judicial se juega fundamentalmente en la calidad juridica y moral de sus decisiones.

En reciente comentario, la ex magistrada Dra. Mariana Mota, luego de observar que la decisión "contradice frontalmente la anterior adoptada por ese mismo organismo respecto de la ley 15.848", la ha criticado como "respuesta que la justicia da a los crímenes más graves cometidos contra la persona humana en un contexto de sistemática y masiva vulneración de derechos ocurrida en tiempos de dictadura" señalando que "pronunciamientos como el que venimos de analizar, que no mira por las consecuencias gravisimas que derivan de su decisión, se traduce en una justicia que no afronta las conductas aberrantes, pero además que no cumple con la función principal que es la de decir el derecho ante el requerimiento de los justiciables a través de un proceso desarrollado con garantías procesales" $\left.{ }^{45}\right)$.

La crítica apunta a cuestiones realmente cruciales.

Es evidente que la decisión mayoritaria implica un cambio radical respecto de lo que la Suprema Corte sostuvo en la sentencia 369/2009 -también redactada por el Ministro Chediak cuando asumió su cargo, ocho años antes- tanto por que se resolvió, remover el obstáculo para investigar los hechos del pasado, como en su expresión de fundamentos, en la que seguía la mejor doctrina, con beneplácito general, incluso de la Corte Interamericana de Derechos Humanos. La nueva jurisprudencia contradice lo dicho entonces acerca de la relevancia del derecho internacional de los derechos humanos, reconocido como ius cogens y citando ampliamente precedentes de la Corte Interamericana de Derechos Humanos a los que se atribuía singular valor. Se desconoce ahora el derecho reconocido entonces a las victimas y sus familiares "de acceder al sistema judicial para que se identifique y castigue a los presuntos culpables de los hechos acaecidos durante la dictadura militar» ${ }^{\left({ }^{46}\right)}$.

Ese cambio de orientación debía haber sido justificado haciendo una revisión crítica de los argumentos expuestos entonces, como es de rigor cada vez que un órgano jurisdiccional varía su jurisprudencia y, más aún, tratándose de un tema harto sensible. Por demás, tal cambio debía ser especialmente justificado ya que marca un retroceso en materia de protección de derechos humanos y vuelve a la defensa de la impunidad.

Desde un enfoque de teoría de la decisión judicial, es también evidente -como señala con acierto la crítica-la decisión mayoritaria nunca podría ser presentada como la mejor lectura posible del derecho actual y menos aún es el esfuerzo que pide Ronald Dworkin, para alcanzar el ideal de «la única respuesta correcta».

Como es evidente, la función de los jueces es especialmente trascendente para la vigencia efectiva del «Estado constitucional de Derecho» cuya legitimidad social funda

${ }^{45}$ MOTA, Mariana «Crímenes de lesa humanidad, imprescriptibilidad, irretroactividad de la ley penal» Revista de Derecho Penal 25, Montevideo, FCU, 2017 p.337-346.

${ }^{46}$ SCJ 365/2009. 
precisamente en la protección de derechos que son esenciales para cualquier proyecto de vida personal autónomo. Por eso importa que exista un sistema judicial independiente e imparcial, fuertemente comprometido y proactivo en la tutela judicial de los derechos de todos. No puede perderse de vista que la Suprema Corte de Justicia, es el intérprete último de la Constitución Nacional en el orden interno y sus decisiones son la última garantía que tienen las personas en ese ámbito, y que ellas lo saben y lo exigen $\left({ }^{47}\right)$.

$\mathrm{Al}$ mismo tiempo la tarea judicial es más visible que nunca y esa visibilidad sirve al control ciudadano su actuación. El Poder Judicial, como poder estatal se legitima en una sociedad democrática no sólo por la elección parlamentaria de los integrantes del máximo órgano del sistema, pero también tomando decisiones que cumplan con estándares de corrección que, racional y razonablemente, pueden exigirse a esa institución en una sociedad republicana y democrática.

\section{EL PESO DE OTRAS RAZONES}

Aunque aquí me propuse enfocar el problema desde una perspectiva de la argumentación jurídica, es imposible soslayar que esta cuestión es relevante desde otras perspectivas que gravitan con mucho peso sobre las decisiones prácticas. No es posible ignorar que las razones de corrección moral y las razones políticas tienen indudable incidencia sobre nuestras decisiones interpretativas, especialmente en asuntos controversiales.

\subsection{Un punto de vista moral.}

Es ampliamente admitido hoy que en la toma de decisiones prácticas, y las decisiones judiciales lo son, pesan siempre razones morales. Todas las concepciones actuales del Derecho aceptan que el razonamiento jurídico no excluye la reflexión moral y no niegan valor a las razones morales. Incluso, alguna concepción teórica presenta al derecho como un sector específico de la moralidad, concretamente de la moral política $\left.{ }^{48}\right)$.

Desde luego, esto no significa que los jueces estén autorizados a decidir prescindiendo de las normas del sistema jurídico, sino tan solo de admitir que sus decisiones son, de algún modo, decisiones interpretativas del derecho vigente en que juegan preferencias valorativas. La idea es que la interpretación constitucional procure comprender lo mejor posible las palabras de la Constitución como expresión de un acuerdo sobre un gobierno justo y eso implica "esforzarnos al máximo, dentro de las limitaciones de la interpretación, para hacer de la ley fundamental de nuestro país lo que nuestro sentido de la justicia aprobaría...»(49)

El descuerdo en cuestiones que nos parecen moralmente importantes es un hecho corriente, pese a lo cual la discusión moral no es una práctica frecuente entre nosotros, al menos entendida como deliberación racional acerca de lo que moralmente corresponde hacer. No estamos familiarizados con ese tipo de debates y nos cuesta dar razones en apoyo de nuestras convicciones morales más firmes.

\footnotetext{
${ }^{47}$ CASTRO, Alicia. «Los jueces en la mira» en Revista Judicatura N 44, Montevideo, 2006, p.69-77

${ }^{48}$ DWORKIN, R. Justicia para erizos (2011). Trad. H.Pons, B.Aires, Fondo de Cultura Económica, 2014

${ }^{49}$ DWORKIN, R. obra citada p.502-503
} 
Desde una perspectiva bastante generalizada el dilema moral parece plantearse por muchos como opción entre verdad y justicia o indiferencia e impunidad, mientras que para otros es más complejo que eso.

De todos modos, no advierto que existan razones morales para apoyar una interpretación constitucional que prefiere cerrar el camino a la investigación de graves agresiones a sus derechos humanos, permanecer indiferente ante reclamos de quienes afirman haber sido sus víctimas y defender la impunidad de quienes, desde lugares de autoridad, agredieron sistemáticamente los derechos que debían garantizar. Jamás podría ser aceptada como la mejor lectura posible de nuestra Carta Fundamental.

\subsection{El punto de vista político.}

Sintetizando la experiencia de lo ocurrido, Pablo Galain expresa que «En Uruguay la dictadura cívico-militar actuó como un "Estado Terrorista» ejerciendo un gobierno de facto para garantizar la "seguridad nacional» y el "desarrollo" de un modelo económico capitalista. Estos aparatos organizados de poder se convirtieron en dueños de la vida y de la muerte de los opositores políticos de sus regímenes. El miedo, el terror, la tortura, la desconfianza, el individualismo la desinformación y el temor a una desaparición forzada fueron las características de la "lucha contra la subversión".... "la unión de de las inteligencias militares apoyadas por la CIA y por miembros del ejército francés con experiencia adquirida en "guerras sucias" en Africa y Asia permitió el trabajo organizado del terrorismo de estado más allá de las fronteras nacionales (Plan Condor)" que alcanzó a todos los disidentes "convertido en sospechosos, subversivos y sediciosos como primer paso para ser posteriormente considerados enemigos internos.. a quienes se podía desaparecer..." Además de esos crímenes, "la dictadura cercenó todas las libertades, cometió delitos contra la propiedad y también realizó negocios ilícitos de los que nunca tomó conocimiento la justicia» $\left.{ }^{(50}\right)$.

Completando ese marco, un estudio de Burt, Fried y Lessa recuerda el costo humano de la dictadura uruguaya: "entre 1973 y 1977, Uruguay tenía el mayor porcentaje de presos políticos per cápita en el mundo, con más de 60.000 detenidos y unos 6.000 prisioneros de largo plazo. Alrededor de 200 uruguayos / as fueron desaparecidos / as por la fuerza; la mayoría en Argentina, en el marco del Plan Cóndor, pero también en Uruguay mismo. Varios niños y niñas, detenidos/as con sus padres o nacidos/as en cautiverio, fueron separados/as de sus familiares para ser adoptados/as ilegal y clandestinamente por familias de militares y policías, robándoles su identidad y alterándola en secreto. Alrededor de 250.000 uruguayos/as se vieron obligados/as a exiliarsen. En síntesis, afirman que Uruguay «fue la aproximación más cercana al estado orwelliano totalitario en América del Sur» $\left({ }^{51}\right)$.

Todos recordamos que, hacia el final de la dictadura, se concertó un pacto político entre altos mandos militares y algunos dirigentes políticos en el que, según la opinión generali-

${ }^{50}$ GALAIN PALERMO, Pablo (Ed.) A modo de introducción en ¿justicia de transición? Mecanismos políticos y jurídicos para la elaboración del pasado. Valencia, Tirant lo blanch, 2016, p.25-32. La cita está en p.27-28

${ }^{51}$ BURT, Jo-Marie, FRIED AMILIVIA, Gabriela y LESSA, Francesca «La sociedad civil y el resurgir de la lucha contra la impunidad en Uruguay (1986---2014)» en International Journal of Transitional Justice, 2013, p.1- 22. http://alternativas.osu.edu. 
zada, se acordaron condiciones -que permanecen ignoradas hasta hoy- para el retorno al régimen constitucional y democrático. De ese modo a fines de 1984 se hicieron elecciones, con exclusión de algunos partidos y candidatos, y entre el 15 de febrero y el 1 de marzo de 1985 asumió el gobierno electo.

6.2.1. La justicia de transición. En ese contexto, nuevo para nosotros aunque vivido por otras sociedades desde mediado del siglo pasado, se plantea el problema de la transición y, en particular, de la justicia respecto de los hechos criminales cometidos por quienes ejercieron el poder en el período de quiebre institucional.

La idea de una «justicia transicional» está aún en construcción pero su objetivo es claro: procura la pacificación social, sobre la base de poner punto final a prácticas inaceptables desde la perspectiva de los derechos humanos y de procesar lo ocurrido en el pasado reciente mediante reconstrucción de la verdad, juicios de responsabilidad y reparación de las víctima. Como dice Engelhart, "el objetivo de hacer justicia con el pasado procura dar mecanismos indicadores de la forma de reaccionar a los crímenes contra los derechos humanos que todavía no han sido tratado apropiadamenten. Se entiende que sólo así puede lograrse una paz duradera, con fortalecimiento de la democracia y del Estado de Derecho $\left({ }^{52}\right)$.

En la misma línea, Galain insiste en que se trata de "un modelo de justicia asociado a períodos de cambio político, que pretende encontrar respuestas políticas y legales para enfrentar los crímenes cometidos por regímenes represores anteriores" en el entendido de que ese conflicto del pasado tiene repercusiones presentes y que habrán de perdurar $\left({ }^{53}\right)$.

Como concepto político, es claro que no hay un modelo único de justicia transicional, porque siempre es preciso balancear el ideal con las posibilidades reales, por lo que cada transición tiene su propia lógica y características que la tornan única y le obliga a decidir cuándo, cómo y a quienes investigar y también cuánto hay que olvidar para asegurar a la vez, la institucionalidad y la convivencia pacífica $\left({ }^{54}\right)$.

El caso uruguayo es, en cierto sentido, especial porque, según anota el autor, «el pueblo no parece sentir responsabilidad por los crímenes del pasado reciente cometidos en nombre de la "seguridad nacional para el desarrollo económico", no comparte el sufrimiento de las víctimas, no tiene mucho interés en la investigación y castigo de los responsables..." y conjetura que, tal vez se deba al éxito de cierto discurso impuesto desde el inicio de la transición, que explicó la dictadura como consecuencia de la actuación revolucionaria de grupos de izquierda, logrando dirigir la atribución de responsabilidad hacia las víctimas, como iniciadores de la violencia que nos perjudicó a todos. Ese discurso exhortaba a no mirar hacia atrás para poder tener un cambio en paz $\left({ }^{55}\right)$. De ese modo, la justicia transicional no tendría lugar y al plantear la necesidad de "una salida honorable para los militares" y "afirmar que no habrá revancha» se proponía la impunidad y el olvido de todo lo que hubiera ocurrido $\left.{ }^{56}\right)$.

${ }^{52}$ ENGELHART, Marc. «Objetivos de la justicia de transición» en GALAIN PALERMO, Pablo (Ed.) ¿Justicia de transición? Mecanismos políticos y jurídicos para la elaboración del pasado. Valencia, Tirant lo blanch, 2016, p.35-70. Cita en p.36

${ }^{53}$ GALAIN, trabajo citado p.31

${ }^{54}$ GALAIN, trabajo citado p.31-32

${ }_{55}$ GALAIN, trabajo citado p.29-30

${ }^{56}$ PEREIRA, Marcelo. 1980-1984. Operación Sanguinetti, Montevideo, Centro Uruguay Independiente, 1985 p.79. Hay muchísima literatura sobre lo ocurrido en ese período, lo explícito y lo implícito, que es ampliamente conocida. 
De todas estas cuestiones quisiera comentar dos aspectos: el argumento de la salida pactada y el de las dos consultas al cuerpo electoral realizadas en 1989 y 2009.

6.2.2. La salida pactada. Con base en la salida negociada, se ha entendido que la impunidad es un precio a pagar a cambio del retorno a la democracia.

Siguiendo la lógica del discurso militar, según la cual hubo una guerra interna en la que debieron enfrentar un enemigo encubierto -la mítica "subversión»- debía haber amnistía para los dos bandos y eso habría estado implícitamente incluido en el Pacto del Club Naval.

No hay razones para aceptar esa tesis pero, en todo caso, si lo acordado hubiera incluido esa condición, el compromiso sólo podía obligar personalmente a quienes participaron en ese pacto. La negociación se hizo con representantes políticos de ciertos sectores partidarios elegidos por el gobierno de facto como interlocutores, excluyendo expresamente a líderes políticos indiscutibles de dos de los cuatro partidos invitados, y nada indica que la ciudadanía les hubiera conferido plenos poderes para pactar la impunidad.

Sin desconocer que el tema ha dado lugar a discusión, comparto el enfoque de quienes sostienen que este tipo de cuestiones conciernen a derechos irrenunciables que, por añadidura, en el caso corresponden a otras personas y no pudieron ser objeto de una transacción legítima que deba ser respetada. Por demás, el sistema político ha negado ese acuerdo y decisiones del Ejecutivo y del Parlamente han despejado los obstáculos para la investigación y juzgamiento de los hechos. Resulta paradójico que sea la Suprema Corte de Justica, que abrió la brecha de la impunidad en el año 2009, quien ahora la defienda, queriendo levantar una muralla, según la desafortunada metáfora de uno de sus Ministros.

\subsubsection{Los plebiscitos de 1989 y 2009 .}

Desde lo político se ha hecho el argumento que llamaría «la objeción democrática», que señala que la expresión de la voluntad ciudadana en el plebiscito que desestimó el recurso de referéndum contra la Ley de Caducidad (1989) y luego, en el que rechazó la propuesta de reforma constitucional para la anulación de la misma ley (2009), debe interpretarse como voluntad nacional de aprobar la impunidad.

Quien ha formulado ese argumento con mayor seriedad -a mi juicio- ha sido el filósofo y jurista argentino Roberto Gargarella, en su crítica a la sentencia de la Corte Interamericana en el Caso Gelman vs. Uruguay $\left({ }^{57}\right)$.

Gargarella abraza con verdadero fervor el ideal habermasiano de la democracia deliberativa y parece rechazar con determinación cualquier idea que pretenda sustraer derechos fundamentales a la decisión de las mayorías, como la esfera de «no decidible» de que habla L.Ferrajoli o el «coto vedado» de E. Garzón Valdés.

No cabe duda de que la idea de una democracia deliberativa es un ideal regulativo incuestionable, pero nuestras democracias reales están lamentablemente muy lejos de ese modelo ideal, que requiere ciudadanos formados en el ejercicio del sentido crítico e informados sobre las cuestiones de interés público sobre las que deben decidir y requiere,

${ }^{57}$ GARGARELLA, Roberto. «Justicia penal internacional y deliberación democrática» en SANTOLAYA MACHETTI, Pablo - WENCES, Isabel (Coord.) La América de los Derechos, Centro de Estudios Políticos y Constitucionales, Madrid, 2016. p.409-433. 
además, ámbitos adecuados de discusión donde puedan participar en igualdad de condiciones todas las personas concernidas por el asunto a decidir. La democracia deliberativa es un ideal regulativo altamente valioso y es claro que basta en votar de vez en cuando para elegir entre listas de gobierno o votar sí o no en consultas sobre cuestiones complejas que no han sido objeto de un debate amplio y participativo.

Quienes hemos vivido los dos plebiscitos sabemos que en cualquiera de las dos instancias, la consulta popular fue por sí o por no, sin haber sido precedida de un debate amplio y participativo centrado en el análisis de razones, y tuvieron lugar en contextos marcadamente condicionantes. En el primero fuimos llamados a votar bajo la presión política de una supuesta amenaza militar a la recién reconquistada democracia y de un discurso que nos incitaba a no mirar hacia atrás ("no tener los ojos en la nuca»). En el segundo, se planteaba una cuestión jurídica harto discutible-una reforma constitucional para anular una ley- que nunca fue cabalmente explicada a la ciudadanía por quienes la impulsaron $\left({ }^{58}\right)$.

En suma, nunca se plebiscitó una propuesta de amnistía para los funcionarios militares y policiales que habían participado en violaciones graves de los derechos humanos. Se intentó un recurso de referendum para dejar sin efecto una ley declaraba la caducidad de la pretensión punitiva del Estado y ese referendum fracasó. Luego se intentó una reforma constitucional para anular esa misma ley y también fracasó $\left({ }^{59}\right)$.

Desde lo político hubo particular empeño en leer el resultado del referendum como un respaldo del cuerpo electoral a la amnistía de militares y policías y también en leer el fracaso de la reforma constitucional en el mismo sentido, pero la motivación del voto ciudadano nunca obedece a una única razón, ni tiene siempre una única lectura posible.

Por otra parte, cabe preguntarse si el supuesto respaldo de la ciudadanía puede convertir en legítima una ley que no lo es. Así lo observó la Suprema Corte de Justicia en la reiteradamente citada sentencia SCJ 365/2099 y entendió que no, adhiriendo a la idea garantista de que los derechos humanos, en tanto bases fundamentales que deben asegurarse a todas las personas al construir un sistema institucional que ha de ejercer el poder público, son un reducto que debe quedar blindado ante las decisiones políticas que puedan tomar mayorías contingentes.

Ese argumento puede defenderse aún sin poner en duda que "la decisión política democrática tiene un valor intrínseco y proporciona una clase de legitimidad que no puede encontrarse en otras formas de gobierno" $\left({ }^{60}\right)$. En primer lugar porque derechos de rango constitucional no pueden ser suprimidos por ley ni aún invocando razones de interés general y, en segundo lugar, porque decisiones como la que se discute -no juzgar crímenes de lesa

${ }^{58}$ Luego del fracaso, un sector fuerte en votos expresó su pesar por no haber «ensobrado» la papeleta con sus listas, dando por cierto que de ese modo se habrían obtenido los votos faltantes, lo que es indudablemente cierto, pero también dice mucho la idea subyacente: el ciudadano votó lo que tenía en el sobre del sector político que quería votar. Donde está entonces la deliberación racional sobre la propuesta plebiscitada?

${ }_{59}$ En el referendum de 1989 el voto contra la Ley de Caducidad obtuvo 42,4\% contra 57,6\% a favor y en el plebiscito de 2009 los resultados fueron de 52,64\% contra 47,36\%.

${ }^{60}$ MARQUISIO AGUIRRE, Ricardo. "La idea de una autoridad democrática» en Revista Facultad de Derecho $\mathrm{N}^{\circ}$ 40, (UDELAR) Montevideo, 2016, p.189. 
humanidad- exceden el marco de lo que puede decidir una comunidad estatal, porque en esa materia los Estados han declinado su soberanía y han cedido su regulación a la comunidad internacional. Lo cual no sólo fue una decisión tomada dentro del marco democrático, sino que se justifica porque es la mejor forma de defensa de esos valores compartidos contra agresiones que provienen de autoridades ilegítimas que ejercen terrorismo de Estado. Por tanto, la comunidad relevante y, en definitiva, la autoridad legítima en estos temas es la comunidad internacional y, en el sistema regional, hemos reconocido la jurisdicción de la Corte Interamericana. El derecho a una tutela judicial efectiva forma parte de ese recinto protegido por normas jurídicas internacionales y ningún Estado está habilitado para decidir contra normas calificadas de orden público internacional.

\section{RECAPITULANDO.}

Como se trata de un debate que permanece abierto, mi defensa de una de las posiciones en pugna ha pretendido ofrecer argumentos que entiendo como aportes a la discusión, consideraciones a tener en cuenta especialmente por quienes se propongan defender derrotarlos en defensa de la posición contraria, cuya justificación, por ahora, es claramente insatisfactoria.

En síntesis:

1. En materia de derechos humanos el derecho aplicable según la Constitución de la República, no se limita al derecho interno sino que remite a todo el derecho creado en el orden internacional. No es jurídicamente admisible juzgar los delitos que agredieron sistemáticamente derechos humanos, soslayando la normativa de carácter supranacional.

2. En ese ámbito, se ha impuesto una construcción jurídica destinada a blindar los derechos fundamentales, que habla de normas de "orden público internacional» (ius cogens), de mecanismos de supervisión periódica, de precedentes jurisdiccionales vinculantes y de control de convencionalidad a cargo de los jueces nacionales.

3. De acuerdo con esa normativa ningún Estado puede rehusarse a investigar y sancionar como crímenes de lesa humanidad, ciertas violaciones de los derechos humanos, cualquiera sea el tiempo en que hayan ocurrido. A su vez, todos los Estados del sistema interamericano tienen el deber de cumplir las sentencias dictadas por la Corte Interamericana de Derechos Humanos

4. Ninguna consideración jurídica de derecho interno o de conveniencia política puede justificar el incumplimiento de ese deber, que compromete la responsabilidad del Estado.

5. La impunidad en Uruguay es parcial -porque han habido algunas condenas- y no parece imputable a los jueces, que en general asumieron una actitud receptiva y proactiva, llegando hasta donde han podido, aunque con enormes dilaciones.

Si la justicia no ha logrado su objetivo, ha sido por obstáculos legales, por resistencias que encontró en la investigación y para la prueba, por chicanas de los abogados de los indagados, por traslados de jueces y, en ocasiones, también por decisiones jurisdiccionales de sus superiores procesales.

6. En esta materia la jurisprudencia constitucional ha sido problemática. Resulta paradójico que la Suprema Corte de Justicia demorara veinte años en declarar inconstitucional a la Ley de Caducidad y, superado el obstáculo, dicte decisiones contradictorias sobre 
la prescripción de los delitos amparado por esa ley, pareciendo consolidarse como mayoritaria la tesis favorable a la extinción de esos delitos. Ese cúmulo de circunstancias ha generado desconcierto y desconfianza que perjudican la imagen institucional del Poder Judicial, que no aparece como último reducto garantista sino último reducto de la impunidad cuando los otros poderes del Estado han cambiado notoriamente su actitud.

7. No es jurídica ni moralmente defendible una opción que signifique priorizar derechos de los agresores sobre derechos de las víctimas de violaciones de derechos humanos.

\section{BIBLIOGRAFÍA CONSULTADA}

ABRAHAN, Manuela.»El Poder Judicial durante el terrorismo de Estado en Uruguay. Un enclave autoritario ausente del debate» en SERPAJ Derechos Humanos en el Uruguay, Informe 2016,Montevideo, 2016 p.103-115.

ANTKOWIAK, Thomas: "Principio de legalidad y de retroactividad" en STEINER Christian y URIBE, Patricia (Edit.) "Convención Americana sobre Derechos Humanos. Comentario", Buenos Aires, Konrad Adenauer Stiftung, 2014, p.255-262.

BLENGIO VALDÉS, Mariana. "Corte Interamericana de Derechos Humanos. Caso Gelman vs. Uruguay”, Revista de Derecho Público N 39 , Montevideo, FCU, 2011.

BLENGIO VALDÉS, Mariana.»La interpelación de los derechos humanos en veinte años de democracia» en CAETANO, Gerardo (Comp) 20 años de democracia. Uruguay 1985-2005: Miradas múltiples, Montevideo, Taurus, 2005, p.155-192.

BURT, Jo-Marie, FRIED AMILIVIA, Gabriela y LESSA, Francesca «La sociedad civil y el resurgir de la lucha contra la impunidad en Uruguay (1986---2014)» en International Journal of Transitional Justice, 2013 p. 1-22 http://alternativas.osu.edu.

ENGELHART, Marc. «Objetivos de la justicia de transición» en GALAIN PALERMO, Pablo (Ed.) ¿Justicia de transición? Mecanismos políticos y jurídicos para la elaboración del pasado. Valencia, Tirant lo blanch, 2016, p.35-70

FERRER MAC GREGOR, Eduardo. «Eficacia de la sentencia interamericana y la cosa juzgada internacional: vinculación directa hacia las partes (res judicata) e indirecta hacia los Estados parte de la convención americana (res interpretata). Sobre el cumplimiento del Caso Gelman vs. Uruguay» en Anuario de Derecho Constitucional Latinoamericano Año XIX Bogotá, 2013, p.607-638.

GALAIN PALERMO, Pablo (Ed.) A modo de introducción en ¿Justicia de transición? Mecanismos políticos y jurídicos para la elaboración del pasado. Valencia, Tirant lo blanch, 2016, p.25-32.

GARGARELLA, Roberto. "Justicia penal internacional y deliberación democrática» en SANTOLAYA MACHETTI, Pablo y WENCES, Isabel (Coord.) La América de los Derechos, Centro de Estudios Políticos y Constitucionales, Madrid, 2016. p.409-433.

GARRIDO MUÑOZ, Asier. «El vanguardismo universalista de la jurisprudencia de la Corte Interamericana de Derechos Humanos : expansión y contracción del derecho de acceso a la justicia» en MACHETTI, Pablo y WENCES, Isabel (Coord.) La América de los Derechos, Centro de Estudios Políticos y Constitucionales, Madrid, 2016. p.191-214.

LARRIEUX, Jorge T. «Caso Gelman vs.Uruguay. Justicia transicional, Corte Interamericana de Derechos Humanos y control de convencionalidad» en Anuario de Derecho Constitucional Latinoamericano Año XIX Bogotá, 2013, p.589-606

LESSA, Francesca. «Justicia sin fronteras. El juicio por el Plan Condor» en SERPAJ Derechos Humanos en el Uruguay, Informe 2016,Montevideo, 2016 p.25-41.

MARCHESI, Aldo. "Revolución y contrarrevolución en el Cono Sur. La Operación Condor en la guerra fría latinoamericana» en SERPAJ Derechos Humanos en el Uruguay, Informe 2016, Montevideo, 2016 p. $17-24$

MARQUISIO AGUIRRE, Ricardo. «La idea de una autoridad democrática» en Revista Facultad de Derecho $\mathrm{N}^{\circ}$ 40, (UDELAR) Montevideo, 2016

MOTA, Mariana "Crímenes de lesa humanidad, imprescriptibilidad, irretroactividad de la ley penal» Revista de Derecho Penal 25, Montevideo, FCU, 2017 p.337-346.

OCHS OLAZÁBAL, "El fallo de la Corte Interamericana de Derechos Humanos Gelman con Uruguay", Año IV No. 7, La Ley Uruguay, julio 2011; 
PEREZ GONZALEZ, Carmen. «El tiempo y el Derecho en la jurisprudencia de la Corte Interamericana de Derecho Humanos: a propósito de la competencia ratione temporis de la Corte en los casos de desapariciones forzadas» en SANTOLAYA MACHETTI, Pablo - WENCES, Isabel (Coord.) La América de los Derechos, Centro de Estudios Políticos y Constitucionales, Madrid, 2016. p.133-150

PEREZ PEREZ, Alberto. "Las gravísimas violaciones de los derechos humanos ante la jurisprudencia interamericana» en SANTOLAYA MACHETTI, Pablo - WENCES, Isabel (Coord.) La América de los Derechos, Centro de Esrtudios Políticos y Constitucionales, Madrid, 2016, p.87-107.

RISSO FERRAND, Martín. "Cumplimiento de la sentencia de la Corte Interamericana de Derechos Humanos en el caso Gelman. Después de la declaración de inconstitucionalidad de la Ley Interpretativa 18.831» en Anuario de Derecho Constitucional Latinoamericano Año XIX Bogotá, 2013, p.639653.

RISSO FERRAND, Martín. «La ley de amnistía uruguaya, los pronunciamientos populares y las sentencias nacionales e internacionales» en GALAIN PALERMO, Pablo (Ed.) ¿Justicia de transición? Mecanismos políticos y jurídicos para la elaboración del pasado. Valencia, Tirant lo blach, 2016, p.151-

RODRIGUEZ, Roger. «La sempiterna impunidad» en SERPAJ Derechos Humanos en el Uruguay, Informe 2016,Montevideo, 2016 p.50-58

SANCHEZ PATRON, José Manuel "La imprescriptibilidad de los crímenes contra la humanidad en Uruguay» en Revista de la Facultad de Derecho (UDELAR) N²5, Montevideo, FCU, 2006, p.261286.

STEINER, Christian y URIBE, Patricia. «Introducción general» en la obra colectiva compilada por ambos Convención Americana sobre Derecho Humanos. Comentario, Argentina, Konrad Adenauer Stiftung, 2014.

TORREZ ZUÑIGA, Natalia «Control de normas constitucionales por la Corte Interamericana de Derecho Humanos» en SANTOLAYA MACHETTI, Pablo - WENCES, Isabel (Coord.) La América de los Derechos, Centro de Estudios Políticos y Constitucionales, Madrid, 2016. p.483-507.

Fecha de recepción: 3 noviembre 2018.

Fecha de aceptación: 11 noviembre 2018. 